\title{
Biodiversity and ethnobotanical potentials of plant species of University of Agriculture Makurdi Wildlife Park and Ikwe Games Reserve, Benue State, Nigeria
}

\author{
S.O. JIMOH ${ }^{1 *}$, L.A.A.DEBISI ${ }^{1}$ and E.T. IKYAAGBA ${ }^{2}$ \\ ${ }^{I}$ University of Ibadan, Ibadan Nigeria. \\ ${ }^{2}$ University of Agriculture Makurdi, Nigeria. \\ "Corresponding author, E-mail: jimohsaka@yahoo.com
}

\begin{abstract}
Plant biodiversity and ethnobotanical potentials of University of Agriculture Makurdi (UAM) Wildlife Park and Ikwe Games Reserve, Benue State, Nigeria, were investigated in this study. Floristic survey was conducted in the two reserves using stratified sampling technique based on the three identified microhabitats in each of the reserves. Nine plots measuring $25 \mathrm{~m}$ x $25 \mathrm{~m}$ were laid in each of the reserves to survey trees and shrubs with diameters at breast height (dbh) $5 \mathrm{~cm}$ and above. Within each plot, 5 sub-plots of $1 \mathrm{~m} \times 1 \mathrm{~m}$ were established to assess plants below $5 \mathrm{~cm}$ dbh. Participatory ethnobotany and interview were used for the ethnobotanical survey. Seventy-one valuable species belonging to 39 families were identified. Ninety-three percent of these have more than one use; categories with medicinal uses topping the list (48\%). Other uses include: wood $(35 \%)$ and food (17\%). Harvesting techniques in many of the species were intensive and destructive. It is suggested that harvesting of plant products in these reserves be controlled through monitoring and enlightenment.
\end{abstract}

() 2009 International Formulae Group. All rights reserved.

Key words: Biodiversity, ethnobotany, conservation, domestication.

\section{INTRODUCTION}

The existence of plants species in any habitat is crucial to man and other components of the ecosystem as all plants are valuable for one purpose or the other (Olapade and Bakare 1992). Our world has been so closely tied to plants that it is difficult to imagine human existence without them. In recent years, forest products especially the non-timber forest products (NTFPs) have attracted considerable global interest (Barham et al., 1999; Ruiz et al., 1999; Cavendish, 2001). This is due to the increasing recognition of their importance to community needs for improved rural livelihood; household food security and nutrition; employment generation and income supplements. Forests contribute in many ways to combating malnutrition and improving diets in local communities and rural households (FAO, 2000; Karki, 2001; Odebode, 2005; Isichei, 2005; Balemie and Kebebew, 2006; Jimoh and Haruna, 2007). Wild plants constitute the main medicinal resources in many traditional societies.

Furthermore, the problem of food insecurity looms large in developing countries as incidence of poverty is on the increase and defies any precise solution (Odebode, 2005). Millions of the worlds most vulnerable - the rural poors, are facing starvation as food shortage bites hard and prices of food crops move upward every day (Smith and Edward, 2008). They reported that for the first time in history, the effect of food shortage is spreading from developing countries to the developed ones. According to Smith and 
Edward (2008), about 36 countries all over the world now face food crisis.

Forest foods can offer vital insurance against malnutrition or famine during times of seasonal food shortage. It is common for rural households to depend on forest foods. Women, in particular, count on these resources for supplementary nutrition, emergency foods, fuel wood for cooking, medicine, income and many other important products they need to ensure the nutritional well-being of their families (Jimoh and Haruna, 2007; Conservation Africa Foundation (CAF), 2008). Nigeria is blessed with diverse plant species; some of these plants have food value. These plant resources, if properly harnessed would ensure our food security (Isichei, 2005). However, many of these species are under threat of extinction as pressure on them increases. A threat to these plant species means a threat to the survival of the rural poor. This study aimed at identifying plants of economic value in the University of Agriculture, Makurdi Wildlife Park and Ikwe Game Reserve, Igbor, Benue State Nigeria with a view to documenting cultural knowledge about their utilization especially in health care, food security and energy.

\section{MATERIALS AND METHODS}

Study area

This study was carried out at the University of Agriculture Makurdi (UAM) Wildlife Park and Ikwe Game Reserve, Igbor, both in central Benue State, Nigeria. The major ethnic group here is Tiv, while the major occupation is farming. They share overlapping ecological niches, culture and languages. They also share similar climate which is made up of two distinct seasons, wet and dry seasons. The wet season occurs between April and October and the dry season occurs between November to March. Mean Rainfall is between $1000 \mathrm{~mm}-1500 \mathrm{~mm}$. Temperature is $30{ }^{\circ} \mathrm{C}$ and relative humidity is between $60 \%$ and $80 \%$ (Agricultural Resources in Benue State Nigeria (ARB), 2007). The two reserves are located in the Southern guinea savanna. Characterized by relatively fewer trees, more shrubs and predominantly tall grasses, up to $2 \mathrm{~m}$. Some of the species here include Danniellia oliveri, Prosopis africana, Burkia africana, Khaya senegalensis, Stereospermum kunthianum,
Desmodium gangeticum Desmodium velutinum, Ageratum conizoides, Cissus populnea. Andropogon gayanus

UAM Park is located in the lowland of Benue River basin; it has a south oriented slope of 2-5\% (Tyowua, 2002). Located on longitude $08^{\circ} 36^{\prime} \mathrm{E}$ and $8^{\circ} 41^{\prime} \mathrm{E}$ latitude $07^{\circ} 49^{\prime} \mathrm{N} 7^{\circ} 52^{\prime} \mathrm{N}$. UAM Park has a total area of $24.4 \mathrm{~km}^{2}$ and it is located in the Northeastern part of University of Agriculture Makurdi. It is drained by Baa and Najime which are tributaries to River Guma which in turn is a tributary to River Benue. The topography is generally undulating ranging from $83 \mathrm{~m}$ to $167 \mathrm{~m}$ above sea level. The soil is reasonably fertile deep well drained and sandy loam (Tyowua, 2002). It was established by the authorities of the University of Agriculture, Makurdi, Nigeria in 1996 basically for research and biodiversity conservation. It is under the supervision of the Benue State Department of Forestry, Wildlife and Range Management.

Ikwe Game Reserve on the other hand is located in the hill areas of Igbo on latitude $7^{\circ} 30^{\prime} \mathrm{N}$ and longitude $8^{\circ} 30^{\prime} \mathrm{E}$. Topography is highly undulated ranging from $45 \mathrm{~m}$ to $800 \mathrm{~m}$ above sea level. The soil is relatively fertile, shallow, well drained and sandy loam. It covers a total area of about $40 \mathrm{~km}^{2}$ (Abbey, 2006). It is drained by five streams, Aundu and Bai drained the northern part of the reserve, Akuwea-arite and Tyumando are in the central part while Ete is found in the lower part. The reserve was created in 1980 by the Benue State government with the aim of promoting ecotourism and biodiversity conservation (Abbey, 2006).

\section{Data collection and analysis \\ Data collection}

Each forest reserve was stratified into three based on the three microhabitats identified in each reserve for the floristic survey. For UAM these included: forest, savannah and farmland microhabitats, while for Ikwe it included: forest, savannah woodland and hilly terrain. . Nine (9) sample plots of equal size $25 \mathrm{~m} \times 25 \mathrm{~m}$ were randomly laid in each reserve (Sulivan and Sulivan, 2006). This comprises of three sample plots in each microhabitat. Within each plot, five sub-plots of $1 \mathrm{~m} \times 1 \mathrm{~m}$ were established to assess herbs. Within the $25 \mathrm{~m} \mathrm{x}$ 
$25 \mathrm{~m}$ plots, all vascular plants measuring $5 \mathrm{~cm}$ diameter at breast height $(\mathrm{DBH})$ and above were indentified to species level and enumerated. Herbs and other plants less than 5 $\mathrm{cm}$ DBH were studied within the $1 \mathrm{~m} \times 1 \mathrm{~m}$ sub-plots (Obioho, 2005). The identification of plants on the field was done following Keay (1989), Ghazanfar (1989) and Agishi (2004). Samples of plants species which could not be identified on the field were collected and sent to the herbarium of the Forestry Research Institute of Nigeria, Ibadan for identification.

Two main techniques were used for ethnobotanical data collection. These are participatory ethnobotany and artifact/ interviews method, following Martin (1999) and Balemie and Kebebew (2006). This was carried out concurrently with basic fieldwork in floristic survey. One hundred and fifty four randomly selected respondents including seventy-five in UAM Park and 79 in Ikwe Game Reserve were involved in the interaction.

Semi-structured questionnaire was used to collect data on cultural and other uses of wild plants by the people around the reserves. Oral interviews and group discussions were also held with targeted informants including traditional medical practitioners, firewood and herb sellers, farmers, charcoal producers, black smiths.

\section{Data analysis}

Descriptive analyses such as percentages and chart were uses to determine the level of use of the identified plant species. To estimate the cultural significance and level of utilization of each species, Cultural Importance Index (CI), as used by Pardo-deSantayana et al. (2007) was used with the following formula:

$$
C I=\sum_{i=1}^{i=N U} \frac{U R_{i}}{N}
$$

Where $\mathrm{CI}=$ cultural importance,

UR = use reported in every use-category,

$\mathrm{i}=$ varying from only one to the NU,

$\mathrm{NU}=$ total number of uses and

$\mathrm{N}=$ number of informants in the survey.

The CI was calculated for each reserve, for instance, Prosopis africaana in UAM Park was reported being used in medicine by 23 respondents, food by 45 respondents and wood products by 42 respondents. The total number of informants was 75 .

Hence, CI for Prosopis africana $=23 / 75+45 / 75+42 / 75=1.4$

This additive index takes into account the spread of use (number of informants) for each species and versatility, i.e. diversity of uses. Higher CI values imply greater use intensity of a particular plant.

\section{RESULTS}

Seventy-one useful plant species from 39 families were identified (Table 1). Out of this number, $50(70.4 \%)$ were trees, $9(12.7 \%)$ were shrubs, $9(12.7 \%)$ were herbs while 3 $(4.2 \%)$ were climbers. In terms of family representation, Caesalpiniaceae was the most represented with 7 species.

The use of plant by the local people was grouped into three major categories; viz: medicinal uses, food and wood/construction with food and wood having sub-groups of uses. Sixty-eight species (48\%) were used for medicine, 25 (17\%) for food and $50(35 \%)$ for wood/construction. Ninety-three percent of the species have more than one use with medicinal value having the highest value $48 \%$ (Table 1 and Fig. 1).

\section{Cultural knowledge and uses diversity of plants in the study area}

The result of this study shows that the people especially the elderly ones have good knowledge of plant species around them. Of the 71 species recorded in the two reserves, informants in UAM Park were able to give information on 67 of the species recorded while informants in Ikwe supplied information on 66. The lack of information on some of the species could be due to their absence in the area (Table 1). Sixty-one species were found to be commonly used among the people in the two reserves at different levels. Forty plant species were marketed either as food or wood.

\section{Uses diversity of plants}

Ninety-three percent of the species documented have multiple uses. For instance, Prosopis africana Cissus populnea and Parkia biglobosa were useful in all the three categories (Table 1). The breakdown of the species used in food shows that out of the 25 species, 4 of the plants have more than 1 use. 
S.O. JIMOH et al. / Int. J. Biol. Chem. Sci. 3(6): 1375-1385, 2009

Table 1: Plants encountered, their local names (Tiv), families, uses and cultural importance.

\begin{tabular}{|c|c|c|c|c|c|c|c|c|c|c|}
\hline \multirow[b]{2}{*}{ Local name } & \multirow[b]{2}{*}{ Scientific name } & \multirow[b]{2}{*}{ Families } & \multicolumn{4}{|c|}{ UAM } & \multicolumn{4}{|c|}{ IKWE } \\
\hline & & & $\mathbf{M}^{1}$ & FD & $\mathbf{W} / \mathbf{C}$ & $\mathbf{C I}$ & $\mathbf{M}^{1}$ & FD & $\mathbf{W} / \mathbf{C}$ & CI \\
\hline Asaa & Acacia polyacantha & Mimosaceae & 4 & 0 & $18(\mathrm{~m})$ & 0.29 & 3 & 0 & 12 & 0.19 \\
\hline Yiase & Afzelia africana & Caesalpiniaceae & 23 & 8 & $30(\mathrm{~m})$ & 0.82 & 20 & 5 & 24 & 0.62 \\
\hline Ikyo azenga & Allophylus africanus & Sapindaceae & 9 & 0 & 11 & 0.27 & 0 & 0 & 0 & 0 \\
\hline Seta nor & Anchomones difformis & Araceae & 3 & 0 & 0 & 0.04 & 5 & 0 & 0 & 0.06 \\
\hline Ahur & Annona senegalensis & Annonaceae & 31 & 16 & 12 & 0.79 & 29 & 23 & 14 & 0.84 \\
\hline Maaki & Anogeisus leiocarpa & Annonaceae & 3 & 0 & $13(\mathrm{~m})$ & 0.21 & 5 & 0 & 16 & 0.27 \\
\hline Korkoso & Anthocleista djalonensis & Loganceae & 8 & 0 & 10 & 0.24 & 7 & 0 & 11 & 0.23 \\
\hline Bave-kpuaa & Antidesma venosum & Euphorbiaceae & 4 & 0 & 10 & 0.19 & 3 & 0 & 9 & 0.15 \\
\hline Oso-oso & Aspilia africana & Asteraceae & 8 & 0 & 0 & 0.11 & 12 & 0 & 0 & 0.15 \\
\hline Kouogh & Berlinia auriculata & Caesalpiniaceae & 0 & 0 & 0 & 0 & 11 & 0 & 34 & 0.57 \\
\hline Akorakondu & Bidens pilosa & Asteraceae & 0 & 0 & 0 & 0 & 9 & 4 & 0 & 0.16 \\
\hline Genger & Bombax costatum & Bombacaceae & 19 & 31 & $18(\mathrm{~m})$ & 0.91 & 18 & 33 & 16 & 0.85 \\
\hline Kpine & Bridelia ferruginea & Euphorbiaceae & 20 & 0 & $18(\mathrm{~m})$ & 0.51 & 23 & 0 & 21 & 0.56 \\
\hline Gbagbogon & Burkea africana & Caesalpiniaceae & 18 & 0 & $29(\mathrm{~m})$ & 0.63 & 13 & 0 & 36 & 0.62 \\
\hline Hwertor & Byrsocarpus coccineus & Connaraceae & 10 & 0 & 0 & 0.13 & 12 & 0 & 0 & 0.15 \\
\hline Yogbo & Cassia sieberiana & Caesalpiniaceae & 0 & 0 & 11 & 0.19 & 0 & 0 & 0 & 0 \\
\hline Neer & Ceratotheca sesamoides & Pedaliaceae & 15 & 27 & 0 & 0.56 & 14 & 25 & . & 0.49 \\
\hline Ager & Cissus polpunea & Vitaceae & 25 & 43 & $18(\mathrm{~m})$ & 1.15 & 19 & 39 & 16 & 0.94 \\
\hline Azurugh & Combretum molle & Combretaceae & 8 & 0 & 12 & 0.27 & 5 & 0 & 10 & 0.19 \\
\hline Atiever & Corchorus olitorius & Tiliaceae & 13 & 38 & 0 & 0.58 & 10 & 39 & 0 & 0.62 \\
\hline Irkwar-to & Crossopteryx febrifuga & Rubiaceae & 7 & 0 & 9 & 0.21 & 3 & 0 & 11 & 0.18 \\
\hline Tovor & Cussonia arborea & Araliaceae & 0 & 0 & 0 & 0 & 3 & 0 & 6 & 0.11 \\
\hline Chiha & Daniellia oliveri & Caesalpiniaceeae & 16 & 0 & $33(\mathrm{~m})$ & 0.65 & 14 & 0 & 39 & 0.67 \\
\hline Agalien & Detarium macrocarpum & Caesalpiniaceeae & 4 & 6 & $16(\mathrm{~m})$ & 0.35 & 8 & 5 & 21 & 0.43 \\
\hline Agea & Desmodium gengaticum & Fabaceae & 2 & 0 & $10(\mathrm{~m})$ & 0.16 & 3 & 0 & 16 & 0.24 \\
\hline Ivile/ ikye & Elaeis guineensis & Palmae & 20 & 31 & 0 & 0.68 & 18 & 28 & 0 & 0.58 \\
\hline
\end{tabular}


S.O. JIMOH et al. / Int. J. Biol. Chem. Sci. 3(6): 1375-1385, 2009

\begin{tabular}{|c|c|c|c|c|c|c|c|c|c|c|}
\hline Aninge & Emilia coccinea & Asteraceae & 3 & 20 & 0 & 0.31 & 2 & 23 & 0 & 0.32 \\
\hline Liemen & Entada africana & Mimosaceae & 6 & 0 & 7 & 0.21 & 5 & 0 & 11 & 0.20 \\
\hline Kor & $\begin{array}{l}\text { Erythropleum } \\
\text { suaveolens }\end{array}$ & Caesalpiniaceae & 0 & 0 & 7 & 0.11 & 0 & 0 & 0 & 0 \\
\hline Ishohol & Erythrina senegalensis & Papilionaceae & 0 & 0 & 0 & 0 & 3 & 0 & 9 & 0.15 \\
\hline Tur & Ficus capensis & Moraceae & 3 & 1 & 10 & 0.19 & 5 & 2 & 8 & 0.19 \\
\hline Hon & Ficus ingens & Moraceae & 9 & 0 & 11 & 0.33 & 8 & 0 & 12 & 0.25 \\
\hline Tur & Ficus sur & Moraceae & 16 & 19 & 7 & 0.69 & 14 & 24 & 13 & 0.65 \\
\hline Po & Ficus trichopoda & Moraceae & 0 & 0 & 0 & 0 & 13 & 0 & 8 & 0.27 \\
\hline Yaragum & Fluggea virosa & Euphorbiaceae & 12 & 0 & 2 & 0.19 & 15 & 0 & 5 & 0.25 \\
\hline Ibohogh & Gardenia erubescens & Rubiaceae & 11 & 19 & 0 & 0.4 & 12 & 21 & 0 & 0.42 \\
\hline Hwerza & Grewia venusta & Tiliaceae & 6 & 7 & 0 & 0.17 & 4 & 9 & 0 & 0.16 \\
\hline Ashwer & Hibiscus spp. & Malvaceae & 12 & 26 & 0 & 0.51 & 16 & 28 & 0 & 0.56 \\
\hline Irkwar-gbande & Hymenocadra acida & Euphorbiaceae & 5 & 0 & 8 & 0.17 & 3 & 0 & 6 & 0.11 \\
\hline Ityenger & Justicia schimperi & Acanthaceae & 5 & 17 & 0 & 0.29 & 9 & 21 & 0 & 0.38 \\
\hline Haa & Khaya senegalensis & Meliaceae & 13 & 0 & $19(\mathrm{~m})$ & 0.43 & 16 & 0 & 25 & 0.52 \\
\hline Tyembe & Kigelia africana & Bignoniaceae & 8 & 0 & 2 & 0.13 & 19 & 0 & 1 & 0.25 \\
\hline Nimbiligh & Lannea schimperi & Anacardiaceae & 10 & 0 & 11 & 0.28 & 7 & 0 & 13 & 0.25 \\
\hline Agea hilechame & Lippia multiflora & Verbanaceae & 19 & 0 & 1 & 0.27 & 21 & 0 & 0 & 0.27 \\
\hline Horkura & Lophira lanceolata & Ochnaceae & 8 & 0 & $27(\mathrm{~m})$ & 0.47 & 10 & 0 & 27 & 0.47 \\
\hline Alom & Maytenus senegalensis & Celatraceae & 11 & 0 & 5 & 0.21 & 9 & 0 & 3 & 0.15 \\
\hline Ibua & Parinari curatellifolia & Chrysobalanaceae & 12 & 10 & $13(\mathrm{~m})$ & 0.47 & 8 & 13 & 14 & 0.44 \\
\hline Nune & Parkia biglobosa & Mimosaceae & 21 & 46 & $18(\mathrm{~m})$ & 1.13 & 15 & 48 & 15 & 0.99 \\
\hline Mliama-mwiagh & Paullinia pinnata & Sapindaceae & 8 & 0 & $12(\mathrm{~m})$ & 0.28 & 11 & 0 & 9 & 0.25 \\
\hline Jiragba & Pericopsis laxiflora & Papilionaceae & 28 & 0 & $30(\mathrm{~m})$ & 0.77 & 16 & 0 & 32 & 0.61 \\
\hline Nyihar & Piliostigma thonningii & Caesalpiniaceae & 16 & 0 & 11 & 0.23 & 19 & 0 & 17 & 0.46 \\
\hline Gbaaye & Prosopis africana & Mimosaceae & 23 & 45 & $42(\mathrm{~m})$ & 1.47 & 25 & 47 & 44 & 1.51 \\
\hline Kpikegh & $\begin{array}{l}\text { Psorospermum } \\
\text { corymbiferum }\end{array}$ & Guttiferae & 4 & 0 & 5 & 0.12 & 7 & 0 & 11 & 0.23 \\
\hline Ngaji & Pterocarpus erinaceus & Papilionaceae & 5 & 0 & $17(\mathrm{~m})$ & 0.29 & 3 & 0 & 15 & 0.22 \\
\hline Gbur & Quassia undulata & Simaroubaceae & 8 & 0 & 12 & 0.27 & 6 & 0 & 7 & 0.16 \\
\hline
\end{tabular}


S.O. JIMOH et al. / Int. J. Biol. Chem. Sci. 3(6): 1375-1385, 2009

\begin{tabular}{|c|c|c|c|c|c|c|c|c|c|c|}
\hline Chor & Raphia hookeri & Palmae & 0 & 16 & $29(\mathrm{~m})$ & 0.6 & 0 & 20 & 22 & 0.53 \\
\hline Ipungwa & Saba florida & Apocynaceae & 10 & 3 & $11(\mathrm{~m})$ & 0.32 & 11 & 5 & 9 & 0.32 \\
\hline Ikyura-ukase & Sarcocephalus latifolia & Rubiaceae & 12 & 0 & 6 & 0.24 & 8 & 0 & 11 & 0.24 \\
\hline Kumedugh & Sterculia setigera & Sterculiaceae & 19 & 0 & 8 & 0.36 & 12 & 0 & 5 & 0.22 \\
\hline Umanatumba & $\begin{array}{l}\text { Sterospermum } \\
\text { kunthianum }\end{array}$ & Bignonaceae & 16 & 0 & 9 & 0.33 & 13 & 0 & 10 & 0.29 \\
\hline Amako & Strychnos spinosa & Loganiaceae & 11 & 19 & $13(\mathrm{~m})$ & 0.57 & 13 & 21 & 16 & 0.63 \\
\hline Mho & Syzygium guineensis & Myrtaceae & 8 & 0 & $28(\mathrm{~m}$ & 0.48 & 11 & 0 & 31 & 0.53 \\
\hline Gbache & Tacca involucrata & Taccaceae & 9 & 39 & 0 & 0.64 & 8 & 30 & 0 & 0.48 \\
\hline Kwegh & $\begin{array}{l}\text { Terminalia } \\
\text { avicennioides }\end{array}$ & Combretaceae & 4 & 0 & $19(\mathrm{~m})$ & 0.31 & 7 & 0 & 16 & 0.29 \\
\hline Baguji/Ikpokpua & Terminalia macroptera & Combretaceae & 3 & 0 & $17(\mathrm{~m}$ & 0.27 & 8 & 0 & 18 & 0.33 \\
\hline Shase war & Uapaca heudelotii & Euphorbiaceae & 0 & 0 & 0 & 0 & 11 & 0 & 23 & 0.45 \\
\hline Ikyo & Uvaria chamae & Annonaceae & 15 & 0 & 0 & 0.21 & 13 & 0 & 0 & 0.16 \\
\hline Chamegh & Vitellaria paradoxa & Sopataceae & 25 & 35 & $27(\mathrm{~m})$ & 1.17 & 28 & 40 & 31 & 1.25 \\
\hline Hulugh & Vitex doniana & Verbenaceae & 14 & 31 & 18 & 0.84 & 12 & 37 & 21 & 0.89 \\
\hline Anomadze & Ximenia americana & Olacaceae & 5 & 28 & 0 & 0.44 & 8 & 27 & 0 & 0.44 \\
\hline Akena-akena & $\begin{array}{l}\text { Zanthoxylum } \\
\text { zanthoxyloide }\end{array}$ & Rutaceaee & 12 & 0 & 2 & 0.19 & 0 & 0 & 0 & 0 \\
\hline
\end{tabular}

Note: $\mathrm{M}=$ marketed, $\mathrm{M}^{1}=$ medicine, $\mathrm{FD}=$ food, $\mathrm{W} / \mathrm{C}=$ wood and construction, and $\mathrm{CI}=$ Cultural Importance Index
Tive $\mathrm{A}$ major ethnic group in the study area, $\mathrm{UAM}=$ University of Agriculture Makurdi Wildlife Park.

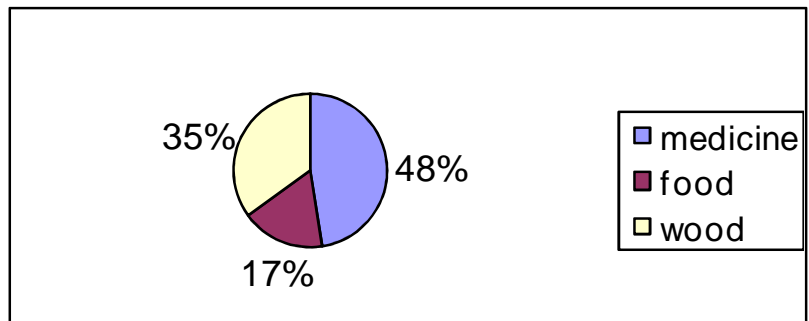

Figure 1: Categories of plants utilization in the study area. 
Table 2: Edible plants in the study area and parts used.

\begin{tabular}{|c|c|c|c|c|c|}
\hline Local name & Botanical name & Raw food & Vegetable & Condiments & Others \\
\hline Yiase & Afzelai africana & & & & Oil (seed) \\
\hline Ahur & Annona senegalensis & Fruit & & - & - \\
\hline Genger & Bombax costatum & & Flowers (m) & & \\
\hline Akorakondu & Biden pilosa & - & Leaves & - & - \\
\hline Neer & $\begin{array}{l}\text { Ceratothecea } \\
\text { sesamoides }\end{array}$ & - & Leaves (m) & & \\
\hline Atiever & Corchorus olitorius & - & Leaves(m) & - & - \\
\hline Ager & Cissus populnea & - & $\begin{array}{l}\text { Fruit leave } \\
\text { stem }\end{array}$ & - & - \\
\hline Ivile & Elaeis guineensis & Nuts (m) & & & Wine $(\mathrm{m})$ \\
\hline Aninge & Emilia cocinea & - & Leaves $(\mathrm{m})$ & - & - \\
\hline Tur & Ficu scapensis & - & Leaves & - & - \\
\hline Tur & Ficus sur & Fruits & Leaves(m) & - & - \\
\hline Ibohough & Gardenia erubescens & Fruits & & & \\
\hline Hwerza & Grewia venusta & Fruits & & & \\
\hline Ashwer & Hibiscus spp & Fruits (m) & Leaves (m) & & \\
\hline Ityenger & Justicia schimperi & & leaves $(\mathrm{m})$ & & \\
\hline Ibua & Parinari curatellifolia & fruit, & & & \\
\hline Nune & Parkia biglobosa & & & Seed, (m) & \\
\hline Gbaaye & Prosopis africana & & & Seed, $(\mathrm{m})$ & \\
\hline Ichor & Raphia hookeri & fruit (m) & & & wine $(m)$ \\
\hline Ipungwa & Saba florida & Fruit & & & \\
\hline Amako & Strychnos spinosa & Fruits & & & \\
\hline Gbache & Tacca involucrate & & & & $\operatorname{Bulb}(\mathrm{m})$ \\
\hline Chamegh & Vitellaria paradoxa & fruits $(\mathrm{m}$ & & & \\
\hline Hulugh & Vitex doniana & fruits (m) & Leaves, (m) & & \\
\hline Anomadze & Ximenia Americana & Fruit(m) & & & \\
\hline
\end{tabular}

Table 3: Distribution of plant species among different forms of wood utilization in the study area.

\begin{tabular}{lcc}
\hline Uses & UAM & IKWE \\
\hline Brick baking & 4 & 4 \\
Charcoal production & 8 & 8 \\
Craft & 7 & 9 \\
Firewood & 42 & 41 \\
Roofing & 4 & 4 \\
Timber & 12 & \\
\hline
\end{tabular}


13 plants were used as raw food either as fruit or nut, 11 were used as vegetables, 2 as condiments and 4 for other sundry uses (Table 2).

Table 3 above presents an analysis of number of plant species in different forms of wood utilization in the study area.

\section{Plants utilization level}

Most of the species in these reserves were found to have high CI values. This suggests that, their harvesting intensities may be high. For instance, Prosopis africana has high average CI value of 1.49 in UAM and 1.51 in Ikwe, Vitellaria paradoxa has 1.17 and 1.25 it was 1.13 am 0.99 for Parkia biglobosa respectively (Table 1). Unfortunately the extraction techniques in many of the species were found to be unsustainable. In the cases of charcoal burning and brick baking species such as Prosopis africana and Afzelia africana were observed being cut for these purposes. Elaeis guineensis and Raphia sp were also observed to be destructively exploited for palm wine. The implication of this for biodiversity conservation and ecotourism potentials of the reserves is grieve. It shows clearly that the goals of establishment of these forest reserves are in serious jeopardy.

\section{DISCUSSION}

\section{Cultural knowledge}

The result of this study shows that the people especially the elderly ones have good knowledge of plant species around them. This confirms the positions of Mbuya et al. (1994), Tuxill (1999) and Bob (2004). The custody of information was not gender sensitive in the study area. Both men and women demonstrated versatility in their knowledge of plants.

The disturbing aspect of the finding is the decay of knowledge about plant and their uses among youths. Interaction with them suggests that, they are far behind and lacking in these areas. Also, the few custodians' especially traditional healers are not always ready to give out the information to stranger. This concern was also expressed by Tuxill (1999).

The high percentage or number of plant species found to be commonly used among the people in the two reserves at different levels could be due to the fact that, the people are of the same tribe (Tiv). The similarity in the knowledge of the people is reflected in the preparation of local soups from these wild species. For instance, preparation of Genger soup with Bombax costatum and Prosopis africana or Parkia biglobosa condiment is common among the people. Also Ager soup prepared using tender leaves or fruits of Cissus populnea is common among the people. Balemie and Kebebew (2006) also reported that people with similar cultural background also share similar diets. The people also share common housing structure, (commonly called thatch house or Itoho in Tiv), normally constructed with the use of Raphia species, Saba florida, Paullinia pinnata, Cisssus populnea, Desmodium gangeticum and Imperata cylindrica.

\section{Uses diversity of plants}

It is a known fact that people everywhere rely on plants for staying healthy and extending the quality and length of their lives. This is true of the people in these areas as they use almost all plants recorded for medicinal purpose. This is similar to the finding of Agbidye et al. (2003).

The high value obtained for medicinal uses is an indication that the use of plant for medical purposes is of great value to the people of the area and it plays a significant role in their health care system. This result is similar to Olufemi (1992), Oluwalana (2001) and CAF (2008). This trend could also be as a result of harsh economic conditions which push conventional medicine beyond the reach of common people and the shortage orthodox medical personnel in rural areas (Olapade and Bakare, 1992; Brown, 1995). This high dependence could also be linked to easy access, affordability, believes in the ability of plants to meet their psychological needs in a way western medicine does not. Brown (1995) and Teklehaymanot and Giday (2007) have similar views. It is, however, incumbent on the management of these two reserves to regulate access to them if sustainability and conservation goals are to be met; failure to do this may spell doom for the future of these two reserves.

Nowhere is the value of biodiversity more evident than in our food supply. The 
result of this study demonstrates that plants still have a key role to play in the diets of millions of people, especially the rural poor. This is similar to the findings of FAO (2000), Odebode (2005), Isichei (2005), Balemie and Kebebew (2006), and Jimoh and Haruna (2007) . Most of the edible fruits are collected by children and in most cases eaten fresh. Examples of such in the study areas include Grewia venusta, Gardenia erubescens, Vitex doniana, Vitellaria paradoxa, Ximenia americana and Annona senegalensis. Some are also moved to the market for commercial purposes. Such species include: Vitellaria paradoxa, Ximenia americana, Vitex doniana. Consumption of these species is of great importance as they have been reported to contain essential vitamins and minerals required in human body. Hence, they serve as cheap sources of these compounds (Udo, 1999; Balemie and Kebebew, 2006). To avoid deadly mistake, women who have good knowledge of these species collect most of the leaves for soups, though soup prepared is taken by all members of the family (Udo, 1999; Jimoh and Haruna, 2007).

The continued increase in the prices of alternative sources of energy has contributed to the high number of plants species being used for fuel wood in the study area. This agrees with FAO (2007) that wood fuel plays significant roles in the day to day lives of rural people. Almost all dry-woods are used as fuel, but some are preferred probably because of certain qualities they possess. This is similar to the work of Abdulrahaman et al. (2006). Tree species such as $P$. erinaceus, $P$. laxiflora, $P$. africana, Terminalia sp, B. auriculata, A. leiocarpa, D. oliveri, $K$. senegalensis, $B$ africana, $V$. paradoxa and $L$. lanceolata are the choice fuel wood species in the study area. Earlier studies by Oladele and Yisa (1989) and Ogunkunle and Oladele (2004) also confirmed this. The former presumed that this may be due to their high calorific values and non smokiness.

Only a few species are used for charcoal, brick baking, craft making, timber and roofing. This could be due to the fact that the users based their selection on qualities like, high burning capacity, durability, attractiveness, size and resistance. Abdulrahaman et al. (2006), reported similar findings. Fire wood collection is done by all
(Men, women and children). This is because firewood marketing has become a major source of income to the people.

Charcoal production is mostly done by young men. This is a lucrative business and many people are involved in it. The species commonly used for this include: $P$. erinaceus, $P$. africana, B. africana, $V$. paradoxa and $L$. lanceolata. Palm wine tapping which is mostly in UAM Park is carried out by young men who do it on commercial bases. Species used are Raphia spp and Elaeis guineensis.

Some of the species recorded have similar uses in other parts of Nigeria and Africa (Sofowora, 1982; Udo, 1999; Verinunbe et al., 1999; Yakubu and Idumah, 2002; Isichei, 2005; Muhamed and Amuss, 2005; Balemie and Kebebew, 2006; Jimoh and Haruna, 2007).

\section{Plants utilization level}

Most of the species found in these reserves had high CI values. This suggests that their harvesting intensity is high. For instance, Prosopis africana has high average CI value of 1.49 and 1.51 in the two reserves. This implies that the species is highly utilized and hence, more of it will be harvested. One can easily relate this to poverty, for which many are looking for means of alleviation. The implication of this pressure is that, many of these species may soon become locally threatened or extinct.

The extraction of these plants may be beneficial in solving some human needs such as food, energy and medicinal needs; their methods of harvesting are destructive and inimical to conservation ideals. This finding agrees with (Agbidye and Igbago, 2003). For instance, method of palm wine tapping and charcoal production normally kills species such as Prosopis africana, Afzelia africana and Elaeis gueneensis.

Time of collection especially for food species is species dependent. For instance, Vitellaria paradoxa fruits are collected between June and August; for Vitex doniana, it is between March and May. The time of collection of these species coincides with the time that food is normally scarce in the rural areas. Some weedy species like Emilia coccinea, Corchorus olitorius, are collected 
during the rainy season, Cissus populnea and Vitex doniana leaves are usually collected during agricultural off-season between March and May. Therefore, these species, if properly coordinated can contribute meaningfully to solving nutrition problem especially now that there is food crisis in many parts of the world.

\section{Conclusion}

The ethnobotanical study conducted in UAM Park and Ikwe Game Reserve presents information with regard to the cultural knowledge and utilization of flora of these reserves. The study indicates that these reserves are endowed with plants of great importance to the surrounding communities. Some of the products derived from the reserves include: medicine, food, wood and energy. Unfortunately, the harvesting techniques are destructive in many of the species. This portends great danger for species diversity and poses serious threats to conservation goals within these protected areas.

The unique biological and cultural importance of these reserves calls for serious overhauling of conservation and sustainable management strategies in the reserves. Harvesting of plant products in these reserves should be coordinated through monitoring and creation of awareness on their values. There is need to educate the old rural folks to properly document their knowledge of plants identification and utilization; and share the knowledge with the younger generation so as to ensure continuity.

\section{REFERENCES}

Abbey ML. 2006. Evaluation of flora resources, and utilization in Akure Games Reserve. Unpublished B. forestry project in the Department of Forestry Wildlife and Range Management, University of Agriculture Makurdi. Nigeria 29 pp.

Abdulrahaman AA, Fajemiroye OJ, Oladele FA. 2006. Ethnobotanical study of economic trees: uses of trees as timbers and fuelwoods in Ilorin Emirate of Kwara State, Nigeria. Ethnobotanical Leaflets, 10: 113120.

Agbidye FS, Igbago GO. 2003. Plant used in traditional medicine in Agatu Local Government Area Benue State, Nigeria. Nigerian Journal of Forestry, 32(182): 110.

Agricultural Resources in Benue State Nigeria.
2005. http//www.benagric.org/contact.htmp

Balemie K, Kebebew F. 2006. Ethobotanical study of wild edible plants in Derashe and Kucha District, South Ethiopia. http://www.publiccentral.nih:gov/reirect3.gi.

Barham BL, Comus OT, Takasak Y. 1999. Rainforest Livelihoods; income generation, Household Health and Forest use. Unasylva, 50(198): 34-38.

Cavendish W. 2001. Non-timber Forest Products And Rural Poverty: An Economic Analysis. Evans J (ed) Forests Handbook Vol. 1. An Overview of Forest Science. Blackwell Science Ltd; 372-390.

Conservation Africa Foundation (CAF). 2008. Non-timber forest products: Breaking the vicious cycle of poverty and degradation in Africa.

http://www.conserveafrica.org.uk/poverty.p $h p$

FAO. 2000. Non-Wood News. An Information Bulletin of Non-wood Forest Products. 95pp.

FAO. 2007. State of the World forest, Rome: pp 5-98.

Isichei AO. 2005. The role of plant resources in Nigeria's economic recovery agenda. Nigeria Journal of Botany, 18: 1-22.

Jimoh SO, Haruna EA. 2007. Contribution of non-timber forest products to house food security and income around Onigambari forest reserve, Oyo State, Nigeria. Journal of Environmental Extension, 6: 28-33.

Keay RJW. 1989. Trees of Nigeria. Oxford Science Publication: New York; 1-498.

Martin CJ. 1999. Ethnobotany: Plants and People. Conservation Manual: London; 367.

Muhamed S, Amusa NA. 2005. The important food crops and plants of North - western Nigeria. http:// www. insinet.net/Ajabs/254 $-260 p d f$

Obioho GIB. 2005. Ecological ethnobotany and Sustainable Forest Management in Omo biosphere reserve Nigeria; Lessons and Prospects: in Popoola L (ed) Proceedings of the $30^{\text {th }}$ Annual Conference of Forestry Association of Nigeria, p.86.

Odebode S. 2005. Contribution of selected non-timber forest products to household food security in Osun State, Nigeria. http://www.aseanbiodiversity.info/scripts /count-article.asp\%/aARtilce-co

Ogunkunle ATJ, Oladele FA. 2004. Ethnobotanical study of fuelwood and 
timber wood consumption and replenishment in Ogbomoso, Oyo State, Nigeria. Environmental Monitoring and Assessment, 19: 223-236.

Oladele FA, Yisa AB. 1989. Frequencies of dominant tree species used as sources of fuelwood in Ilorin Local Government Area, Kwara State. Bioscience Research Communication, 1: 19-24.

Olapade OE, Bakare OA. 1992. Medicinal plants in Ibadan under threat of genetic erosion; Our Forest, Environment and Heritage; Challenges for Our People, Akinsanmi FA (ed). Proceedings of $22^{\text {nd }}$ Annual Conference of Forestry Association of Nigeria Held in Kano, Kano State, Nigeria, pp 55-58.

Olufemi SO. 1992. A survey of Non-wood forest products in Ondo State, Nigeria. Our Forest, Environment and Heritage: Challenges for our People, Akinsami (ed). Proceeding of $22^{\text {nd }}$ Annual Conference of Forestry Association of Nigeria Held in Kano, Kano State, Nigeria, 3-7pp.

Oluwalana ECA. 2001. Indigenous use of forest plant leaves in Ogun State, Nigeria. Journal of Forestry, 31(3): 4957.

Pardo-de- Santayana M, Tardio J, Blanco E, Morales RZ. 2007. Traditional knowledge of wild plants use in the Liberian peninsula (Spain and Portugal): a comparative study. www.ethnobiomed.com content 3127

Ruiz P, Nduoye O, Eyebe A. 1999. Marketing of non-wood forest products in the humid forest zone of Cameroon. Unasylva, 50(198): 12-19.

Smith K, Edward. 2008. The year of global food crisis. http://www.sundayherald.com/ news/display.var.2104849.0.2008-the year of-global-food-crisis .php.

Sofowora A. 1982. Medicinal Planta of Africa. Macmillan Publishers: London.
Sullivan TP, Sullivan DS. 2006. Plant and small mammal diversity in orchard versus non crop habitats. Agriculture Ecosystems and Environment, 116: 235-243.

Teklehaymanot T, Giday M. 2007. Ethnobotanical study of medicinal plants used by people in Zegie Peninsula, Northwestern Ethiopia.

Tuxill J. 1999. Appreciating the benefits of plant biodiversity. http://www. worldwatch.org

Tyowua BT. 2002. Evaluation of vegetable types in wild life park University of Agriculture Makurdi. Unpublished M.Sc thesis the Department of forestry and wood technology University of technology Akure, Ondo State, Nigeria $15-38 \mathrm{pp}$.

Udo EO. 1999 The role of Nigeria rainforest in the nutrition of the people: implication on Biodiversity conservation: Conservation of Nigeira's Natural Resources and the Threatened Environment, Obiaga P.C et al. (eds). Proceeding of the $26^{\text {th }}$ Annual Conference of the Forestry Association of Nigeria held in Maiduguri, Borno State, Nigeria, pp 212-217.

Verinunbe MI, Lur JJ, Amaza LS. 1999. Non timber forest resources (NTFRS) and management of Wuda-Taye Forest Reserve in Borno State, Nigeria. Conservation of Nigeria Natural Resources and the Threatened Envroment, Obiaga et al. (eds). Proceedings of $26^{\text {th }}$ annual conference of Forestry Association of Nigeria Held in Maiduguri, Borno State, Nigeria, pp 132138.

Yakubu FB, Idumah FO. 2002. Processing and Marketing of Charcoal in Selected Local Government Areas of Oyo State, Nigeria: Forestry and challenges of sustainable livelihold, Abu et al. (eds). Proceeding of $28^{\text {th }}$ Annual conference of Forestry Association of Nigeria, Held in Akure Ondo State, Nigeria, pp 65-73. 